The Nuclear Environmentalist 
Juan José Gómez Cadenas

\section{The Nuclear \\ Environmentalist}

Is There a Green Road to Nuclear Energy?

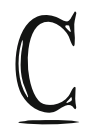

Copernicus Books

An Imprint of Springer Science +Business Media 
Juan José Gómez Cadenas

Consejo Superior de Investigaciones

Científicas and Universidad de Valencia

Valencia

Spain

(C) Juan José Gómez Cadenas, 2012 Original edition El ecologista nuclear, by Juan José Gómez Cadenas

(C) Espasa Calpe, S.A. 2009

ISBN 978-88-470-2477-9

ISBN 978-88-470-2478-6 (eBook)

DOI 10.1007/978-88-470-2478-6

Springer Milan Heidelberg New York Dordrecht London

Library of Congress Control Number: 2011940858

(C) Juan José Gómez Cadenas 2012

This work is subject to copyright. All rights are reserved, whether the whole or part of the material is concerned, specifically the rights of translation, reprinting, reuse of illustrations, recitation, broadcasting, reproduction on microfilm or in any other way, and storage in data banks. Duplication of this publication or parts thereof is permitted only under the provisions of the Italian Copyright Law in its current version, and permission for use must always be obtained from Springer. Violations are liable to prosecution under the Italian Copyright Law.

The use of general descriptive names, registered names, trademarks, etc. in this publication does not imply, even in the absence of a specific statement, that such names are exempt from the relevant protective laws and regulations and therefore free for general use.

\section{Translator: Anahí Seri}

Printed on acid-free paper

Copernicus Books is a brand of Springer

Springer is part of Springer Science+Business Media (www.springer.com) 
It's a black and white photograph, but it captures the light of a summer afternoon in 1959.

The man has a plucky nose, an honest chin, and a moustache in the style of Clark Gable.

The girl is a very beautiful brunette. Her smile is ecstatic; his, incredulous. Both of them, in love.

This year we're celebrating their golden wedding.

To my parents 


\section{Acknowledgments}

Every book is a voyage.

Without my wife Pilar and my children Irene and Hector, it would not have been a voyage but a wreckage.

Without the help of numerous friends and colleagues, it would have been much more difficult to find a safe harbor. The list is long and the memory of the old sailor weak. Thus, I prefer to extend here my acknowledgment to all of them without spelling their names. You all know.

I am grateful for the kindness of the Spanish Nuclear Council and the Foro Nuclear, who have supplied information concerning Spanish nuclear power stations. 


\section{Contents}

$1 \quad$ All that Glitters is not Green $\ldots \ldots \ldots \ldots \ldots$

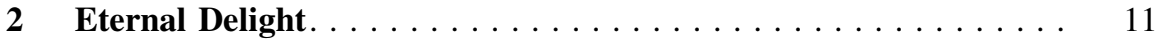

$3 \quad$ A Wasted Inheritance. . . . . . . . . . . . . . . . 17

4 The Ignoble Fuel $\ldots \ldots \ldots \ldots \ldots \ldots$

5 Manna Springing from the Earth $\ldots \ldots \ldots \ldots \ldots \ldots \ldots \ldots$

6 The Sacred Fire $\ldots \ldots \ldots \ldots \ldots \ldots \ldots \ldots \ldots$

7 On Board the Nautilus $\ldots \ldots \ldots \ldots \ldots \ldots \ldots \ldots$

8 The Bequest of a Supernova $\ldots \ldots \ldots \ldots \ldots \ldots$

$9 \quad$ Nuclear Reactors $\ldots \ldots \ldots \ldots \ldots \ldots \ldots \ldots$

10 Nuclear Power, No Thanks? . . . . . . . . . . . . . . . . . . 103

11 The Anti Nuclear Litany. . . . . . . . . . . . . . . . . 125

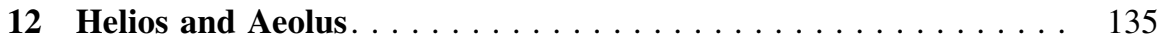

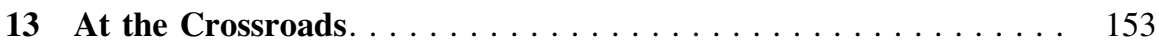

14 Fukushima, or the Black Swan of Nuclear Energy . . . . . . . . . . 161 